безпеки. Відповідна політика безпеки в загальноосвітньому закладі, у вигляді відповідного документа, встановлюватиме правила контролю шкідливого контенту, окреслюватиме шляхи їх реалізації, визначатиме напрямки діяльності щодо забезпечення ІБ всіх суб'єктів освітнього процесу.

Подальших досліджень потребують організаційно-педагогічні проблеми застосування контент-фільтрації під час доступу до ресурсів і сервісів мережі Інтернет у вітчизняних загальноосвітніх навчальних закладах.

\title{
Література
}

1. Богатырева Ю. И. Информационная безопасность школьников в образовательной среде : теория и практика высшей школы / Ю. И. Богатырева. - Тула, 2013. - 160 c. 2. Доктрина забезпечення інформаційної безпеки України [Електронний pecypc]. Режим доступу: http://zakon4.rada.gov.ua/laws/show/514/2009 3. Ковальчук В. Н Методика забезпечення он-лайн безпеки старшокласників у навчально-виховному процесі школи [Електронний ресурс] / В. Н. Ковальчук. Режим доступу: http://www.journal.iitta. gov.ua 4. Краевский В. В. Качество педагогики и методологическая культура педагога / В. В. Краевский. - М. : 1991 212 с. 5. Кузьмина Н. В. Методы системного педагогического исследования / Н. В. Кузьмина. - Л., 1980. - 141 с. 6. Шишкіна М. П Модельний підхід у побудові комп'ютерно-орієнтованого середовища / М. П. Шишкіна. - Суми, 2004. - С. 17-21.

Віктор Шутько

\section{СУЧАСНИЙ ПОГЛЯД НА ПРОБЛЕМИ ФІЗИЧНОГО ВИХОВАННЯ І ФОРМУВАННЯ ОСОБИСТОСТІ ШКОЛЯРА}

Шутько В. В. Сучасний погляд на проблеми фізичного виховання і формування особистості школяра.

Статтю присвячено проблемі оптимального поєднання фізичного виховання 3 іншими видами виховання: розумовим, моральним, естетичним, трудовим, які направленні на формування особистості школяра, для розв'язанння низки важливих проблем, які склалися у фізичному вихованні загальноосвітніх закладів.

Ключові слова: фізичне виховання, формування особистості, гармонійний розвиток, педагогічний процес.

Шутько В. В. Современный взгляд на проблемы физического воспитания и формирования личности школьника.

Статья посвящена проблеме оптимального сочетания физического воспитания с другими видами воспитания: умственным, нравственным, эстетическим, трудовым, которые направлены на формирование личности школьника, для решения ряда важных проблем, которые сложились в физическом воспитании общеобразовательных учреждений

Ключевые слова: физическое воспитание, формирование личности, гармоничное развитие, педагогический процесс.

Shutko V. V. Modern look at the problems of physical education and formation of the individuality of a student.

The article is dedicated to combining physical education with other types of education: intellectual, moral, aesthetic, labor, to the direction of the formation of the individual 
student, in purpose to solve some important problems that have developed in secondary school physical education.

Key words: physical education, forming of the individuality of a student, harmonic development, teaching process.

Проблема формування гармонійної особистості в галузі фізичної культури є не новою. На гармонійний розвиток, заснований на єдності фізичних і духовних сил людини, вказували основоположники теорії фізичного виховання (П. Лесгафт, Я. Каменський, Д. Локк, Ж.-Ж. Руссо, І. Песталоцці). Більшість фахівців визнає, що найбільш оптимальним періодом для цього процесу $є$ етап шкільного навчання, включений у межі педагогічного процесу фізкультурного навчання. Разом 3 цим, останніми роками спостерігається стійка тенденція до погіршення показника здоров'я школярів. Число здорових дітей за період навчання в школі знижується в 4-5 разів. Одним із чинників резистентності організму до розвитку захворюваності в шкільному віці, на думку деяких авторів, є ступінь його функціональної зрілості, пов'язаної 3 рівнями розумового і фізичного розвитку. Дисгармонія між фізичним і розумовим компонентами особового розвитку призводить до зниження функціональних можливостей школярів і виникнення негативних змін у їх здоров’ї. У зв’язку з цим у теорії і практиці фізкультурної освіти проблема гармонізації фізичного і розумового розвитку школярів $є$ надзвичайно актуальною.

Mema cmammi - аналіз сучасних проблем фізичного виховання і формування гармонійної особистості школярів.

3-поміж соціально-культурних проблем, що вимагають негайного розв'язання перед нашим суспільством, виокремлюється проблема формування всебічно розвиненої особистості. В основі характеристик особистості лежать три провідні ознаки: гармонійний розвиток, тобто досягнення адекватного індивідуального рівня розумового, фізичного, трудового, етичного й естетичного розвитку людини в їх взаємозв'язку; соціальна активність людини; готовність до високоефективної професійної діяльності.

У Законі України «Про загальну середню освіту» метою шкільної освіти визначено забезпечення всебічного розвитку шляхом навчання i виховання. Цей процес має відповідати загальнолюдським цінностям і принципам науковості, полікультурності, світському характеру освіти. Перетворення в українському суспільстві докорінно змінили орієнтації в галузі освіти. Нова освітня філософія визначила головну стратегію діяльності: спрямування навчально-виховного процесу на формування духовного світу особистості, утвердження загальнолюдських цінностей, розкриття потенційних можливостей та здібностей учнів.

Важливі компоненти вихованості школярів, які передбачають наявність системи позитивних вчинків, а також сформованість ціннісного ставлення до навколишнього світу, охоплюють такі напрямки:

- ставлення до себе (адекватна самооцінка: бачення власних переваг та недоліків, готовність працювати над розв'язанням проблем самовиховання, самовдосконалення);

- ставлення до друзів, однолітків (вміння розуміти та співчувати, готовність допомогти, виявити терпимість до недоліків інших, здатність пожертвувати своїми переконаннями, інтересами, заради друга);

- ставлення до старших (батьків, учителів), незнайомих людей (уважне ставлення до старших та оточуючих людей незалежно від обставин, вияв поваги до 
батьків, учителів);

- ставлення до праці та громадських доручень (виконання запропонованого громадського доручення, надання допомоги батькам);

- ставлення до природи (вияв любові й поваги до природи, активне піклування про її збереження, відчуття єдності з природою);

- ставлення до суспільства, держави, мистецтва [10].

Нині не можна знайти жодної сфери людської діяльності, не пов'язаної 3 фізичною культурою, оскільки фізична культура і спорт - загальновизнані матеріальні і духовні цінності суспільства в цілому і кожної людини зокрема. Історично фізична культура складалася, передовсім, під впливом практичних потреб суспільства в повноцінній фізичній підготовці підростаючого покоління і дорослого населення до праці. Водночас мірою становлення системи освіти і виховання фізична культура ставала базовим чинником формування рухових умінь і навичок. Якісно нова стадія осмислення сутності фізичної культури пов'язана з іï впливом на духовну сферу людини як дієвого засобу інтелектуального, етичного, естетичного виховання.

Як відзначають деякі автори $[2 ; 3 ; 6]$, фізична культура, на відміну від інших сфер культури, поєднує категорії соціального і біологічного в людині в єдине ціле і $є$ сферою їх гармонізації, сферою ціннісно-орієнтованого розв'язання постійно відтворних суперечностей між ними. Це підтверджується і взаємозв'язком тілесного і духовного в людині, де головним є принцип їх єднання, цілості і гармонії. Отже, гармонія фізичного і духовного - їх нерозривна єдність, повинна бути основною методологічною позицією в підході до процесу засвоєння і вдосконалення людиною цінностей фізичної культури.

Фізичне виховання невід'ємне від інших видів виховання. Органічною основою їх взаємозв'язку $\epsilon$ єдність фізичного i духовного розвитку людини. А також закономірності організації всієї соціальної системи фізичного виховання.

Фізична культура $є$ потужним засобом соціального становлення особистості школярів, активного вдосконалення індивідуальних, особистісних якостей, а також рухової сфери. Тому фізична культура і спорт постають найважливішою умовою, а фізичне виховання - найважливішим засобом різнобічного розвитку особистості. Установка на різнобічний розвиток особистості передбачає оволодіння, з одного боку, основами фізичної культури, складниками якої $є$ міцне здоров'я, гарний фізичний розвиток, оптимальний рівень рухових здібностей, знання та навички в галузі фізичної культури, мотиви і засвоєнні способи (уміння) здійснювати фізкультурнооздоровчу та спортивну діяльність, а з іншого - формування інтелектуальної, вольової та емоційної сфер школяра, його естетичних уявлень і потреб [9].

Поділяє цю думку з доповненням різних форм активних заходів А. Аксьонова, яка стверджує, що фізичне виховання визначається як вид виховання, або спеціалізований педагогічний процес, змістом якого $є$ виховання фізичних якостей, формування рухових умінь і навичок, спеціальних знань і мотивацій на самостійні заняття фізичними вправами і здоровий спосіб життя. Через активну взаємодію школярів під час занять фізичними вправами, через широке застосування таких активних форм навчання, як рухливі та спортивні ігри, естафети, змагальні ситуації, фізичне виховання передбачає формування самостійності, відповідальності, мобільності, організаторських умінь, здатності працювати в парах і групах, брати участь у діяльності в різних ролях позиціях (гравець, ведучий, суддя, контролер і тощо). Окрім того, фізичне виховання на практиці неможливе без розумового, естетичного, морального, трудового виховання, тобто на правильно організованих 
заняттях фізичними вправами формується духовний складник людини, відбувається його соціальний розвиток [1].

Але 3 позицій сьогодення виникають труднощі у розв'язанні перспективних завдань формування особистості, які полягають у масштабному науково-технічному прогресі, високому темпі соціально-економічного життя, змінах у специфіці та змісті трудової діяльності, що значно інтенсифікує навчання школярів.

Аналіз розвитку сучасної системи шкільної освіти в Україні показує, що незважаючи на лавину новацій у системі навчання та виховання, галузі фізичного виховання вони мало стосуються. Навчально-виховний процес загальноосвітньої школи все більше перевантажується предметами, які розвивають тільки розумову діяльність, і при цьому зовсім не враховується зниження рівня фізичного розвитку сучасних дітей і погіршення стану їхнього здоров'я. Водночас відхилення у шкільній практиці від мети фізичного виховання і зведення його до суто нормативного підходу, що спостерігається в останні роки, не тільки суперечить ідеї формування гармонійно розвиненої особистості, але й підсилюе і без того критичний стан здоров'я школярів [4].

Дослідник А. Пивовар визначає, що одним із кризових явищ вітчизняних традиційних і авторських систем освіти $є$ розрив між фізичним вихованням й іншими аспектами виховання дітей молодшого шкільного віку, відсутність реальних механізмів, які обумовлюють взаємозв'язок пізнавальної та рухової діяльності у процесі навчання. Сутьність такої взаємодії полягає у формуванні системи навчання, яка передбачає інтегрований освітній, оздоровчий, загальний виховний ефект як запоруки оптимального розумового і фізичного розвитку дитини, що в наш час $\epsilon$ найбільш актуальним. Фізичний розвиток дитини, вдосконалення іiі пізнавальних процесів, особистих психічних якостей не можна розглядати окремо одне від одного [8].

Трудова діяльність стає дедалі більше пов'язаною 3 підвищенням інтенсивності інформаційних процесів, а це вимагає від особистості високого рівня інтелектуальної напруги, психологічної та рухової працездатності, удосконалення власних здібностей. У зв'язку з цим виникають проблеми інтелектуальної, психологічної і рухової готовності особистості до розв'язання завдань, що постійно ускладнюються, і йдеться не лише про розумову, але й про рухову діяльність, можливості особистості накопичувати й ефективно використовувати свій особистий потенціал. Водночас актуалізується також проблема раціональності рухових дій, тобто особистість може мати високий рівень розвитку рухових здібностей (сили, витривалості, швидкості, спритності) і не мати достатнього інтелекту для того, щоб розумно й раціонально розпоряджатися ними, без зайвих енерговитрат. 3 іншого боку, високий рівень інтелектуальних здібностей за низького рівня фізичної підготовленості також не гарантує успіхів у сучасній трудовій діяльності. Отже, актуальною проблемою сьогодення є гармонійне поєднання й удосконалення інтелектуальних, психічних та рухових здібностей особистості в навчально-виховному процесі. На сучасному етапі такий синтез можливий під час навчання у школі лише на уроках фізичної культури. Йдеться про створення таких педагогічних умов на уроках фізичної культури, які б забезпечували одночасно вдосконалення інтелектуальних, психічних та моторних здібностей молодшого школяра, а також мотивували його до самовдосконалення. Отже, йдеться про забезпечення особистісних досягнень школярів у процесі занять фізичними вправами, які будуть використані в майбутній життєдіяльності [7, с. 104].

Під час створення педагогічних умов, про які зазначив Л. Нечипоренко [7], слід у 
думках змоделювати ту особистість, яка відповідала б вимогам суспільства.

Модель особистості школяра складається 3 шести основних структурних компонентів: поведінковий, мотиваційний, інтелектуальний, емоційно-вольовий, комунікативний, гендерний. Кожен із компонентів має три модельні характеристики, що становлять конкретні психологічні якості.

Поведінковий компонент характеризує зовнішні умови психічної діяльності. Він охоплює тип нервової діяльності, темперамент і характер.

Мотиваційний компонент характеризує внутрішні умови психічної діяльності, які спонукають учня до досягнень. Він складається 3: інтересу до виду діяльності, рівня домагання і ціннісних орієнтацій.

Інтелектуальний компонент забезпечує розуміння предмета, ці якості сприяють оволодінню руховими навичками. Він містить такі модельні характеристики: психомоторику, спеціалізовані сприйняття, оперативну пам'ять, увагу, мислення.

Емоційний компонент забезпечує саморегуляцію, самоконтроль рухової діяльності. Передбачає модельні характеристики: емоційну стійкість, психічну саморегуляцію, вольові якості.

Комунікативний компонент характеризує відносини учнів у спорті: ставлення до вчителя, ставлення до партнерів, до суперників.

Гендерний компонент показує, як школярі висловлюють свою індивідуальність [6].

У досягненні системності поєднання фізичного виховання 3 іншими видами виховання: розумовим, моральним, естетичним, трудовим, спрямованими на формування особистості школяра, насамперед треба розв'язати низку важливих проблем, які склалися у фізичному вихованні загальноосвітніх закладів: віку;

- дуже низький рівень фізичного здоров'я основної частини дітей шкільного

- низька ефективність уроків фізичної культури i слабка організація фізкультурно-оздоровчих заходів у режимі навчального дня;

- неефективне використання канікулярного часу учнів для організації фізкультурно-оздоровчої та спортивної роботи;

- недостатній обсяг навчального часу на обов'язкові уроки фізичної культури;

- зведення педагогічного процесу на уроках фізичної культури до розв'язання приватних завдань, не пов'язані з метою загальної освіти в галузі фізичної культури;

- недостатня увага до освіти учнів у галузі фізичної культури, формування стійких інтересів, мотивацій, потреб і установок на самостійні заняття фізичною культурою і спортом;

- відсутність цілеспрямованої пропаганди цінностей фізичної культури і спорту, здорового способу життя;

- низький рівень методичного забезпечення, а також недостатнє використання новітніх і ефективних фізкультурно-оздоровчих технологій;

- недооцінка значення фізичного виховання педагогічними колективами освітніх установ;

- відсутність традицій фізичного виховання в сім'ї;

- незадовільне фінансове i матеріально-технічне забезпечення фізичного виховання в освітніх установах;

- неузгодженість дій органів освіти, охорони здоров'я та фізичної культури і спорту в питаннях фізичного виховання підростаючого покоління [5].

Однією з болючих проблем на теперішній час у формуванні особистості школяра 
виявлено деструктивний уплив навколишнього середовища. Так, В. Кириченко [4], посилаючись на О. Балакіреву зазначає, що нині спостерігається різке збільшення конфліктних недисциплінованих підлітків, які не здатні до самовладання та самоорганізації. В особливостях їх поведінки закладені приховані схильності до алкоголізму, наркоманії, моральної деградації та правопорушень. Як свідчить статистика, десятки порушень закону вчинені підлітками, котрі не досягли віку кримінальної відповідальності. Визначальна роль у розв'язанні цієї проблеми належить сучасній системі фізичного виховання, яка поступово стає невід'ємною частиною способу життя, що суттєво впливає на освіту, виховання та здоров'я людини. Порушення фізичного і нервово-психічного розвитку дітей виявляються в невротичних станах, дефектах статевого розвитку, зниженні стійкості до чинників ризику, таких як наркотики, токсичні речовини, алкоголь.

Далі у своїй роботі В. Кириченко [4] зауважує, що специфічними патогенними чинниками для школярів є чинники ризику, пов'язані 3 організацією навчальновиховної діяльності: інтенсифікація навчального процесу i неефективна його організація, яка базується в основному на статичних навантаженнях, що сприяє штучному скороченню обсягу рухової активності учнів. Отже, підлітки більшу частину свого часу присвячують сидінню за шкільною партою у класі чи за письмовим столом удома.

Останнім часом спостерігається негативна тенденція - зменшення інтересу до занять фізичними вправами. Головна причина такого ставлення до фізкультури з боку учнів зумовлена низьким рівнем знань про вплив фізичних навантажень на організм людини. Як наслідок, страждає не лише здоров'я підлітків, але і їх пізнавальна сфера, запізнюються у часі процеси соціалізації.

Отже, виникла необхідність: 1) перебудови системи фізичного виховання дітей і молоді на основі принципів гуманістичної педагогіки і психології; 2) посилення уваги до особистості кожного школяра як вищої соціальної цінності, перетворення учня 3 об'єкта соціально-педагогічної дії педагога на суб'єкт активної творчої діяльності на основі формування мотивації до різнобічного i гармонійного розвитку; 3) усвідомлення системності поєднання фізичного виховання 3 іншими видами виховання: розумовим, моральним, естетичним, трудовим, які спрямованні на розв'язання важливих проблем, що склалися у фізичному вихованні загальноосвітніх закладів.

\section{Література}

1. Аксёнова А. В. Идеи социального развития младших школьников в процессе физического воспитания в теории и практике П. Лесгафта и В. Пирусского / А. В. Аксёнова // Психология и педагогика: вестник Томского государственного университета. - 2013. - № 375 - С. 130-134. 2. Безруких М. М. Здоровьесберегающая школа / М. М. Безруких. - М. : МПСИ, 2004. - 240 с. З. Гогунов Е. Н. Психология физического воспитания и спорта: [учеб. пособ. для студ. высш. пед. учеб. заведений] / Е. Н. Гогунов, Б. И. Мартьянов. - М. : Академия. 2000. - 288 с. 4. Кириченко В. Розвиток інтелектуальних здібностей підлітків засобами спортивних ігор / В. Кириченко // Науковий часопис Нац. пед. університету ім. М. П. Драгоманова. Серія № 15. «Науково-педагогічні проблеми фізичної культури» / за ред. Г. М. Артюзава. - К., 2013. - Том 2. - Випуск 7 (33). - С. 108-112. 5. Латыпова И. К. Здоровье детей и проблемы физического воспитания школьников / И. К. Латыпова // Педагогіка, психологія та медико-біологічні проблеми фізичного виховання і спорту: зб. наук. пр. / за ред. Єрмакова С. С. - Х. : ХДАДМ, - 2009. - 
№ 10. - С. 102-105. 6. Личность и её формирование в процессе физического воспитания [Електронний ресурс]. - Режим доступа: http:www.ns-sport.ru/lichnost-s-eeformirovanie-v-processe-fizicgeskogo-vospitaniyapage-25.html.

7. Нечипоренко Л. А. Формування особистісних досягнень підлітків у процесі фізичного виховання/ Л. А. Нечипоренко // Педагогіка, психологія та медико-біологічні проблеми фізичного виховання і спорту : зб. наук. пр. / за ред. Срмакова С. С. - Х. : ХДАДМ, - 2010. №4. - С. 104-107. 8. Пивовар А. А. Поєднаний розвиток фізичних і пізнавальних здібностей дітей 5 і 6 років у процесі фізичного виховання: автореф. дис. на здобуття наук. ступеня канд. наук 3 фізичного виховання і спорту: 24.00.02. «Фізична культура, фізичне виховання різних груп населення» / А. А. Пивовар. - Львів, 2005. 24 с. 9. Родин М. А. Формирование личности старших подростков в условиях учебнотренировочного процесса / М. А. Родин // Физическая культура: научно-методический журнал. - 2003. - №4. - С. 15-18. 10. Шкабура О. Н. Формування ціннісних орієнтацій першокласників [Електронний ресурс]/ О.Н. Шкабура. - 2013. - Режим доступу : http//osvita.ua/school/lessons_summaupbring/34366/.

УДК 373.41

Світлана Якименко

\section{ІНТЕГРАЦЙНІ ПРОЦЕСИ В СУЧАСНІЙ ПОЧАТКОВІЙ ОСВІТІ}

Якименко С. І. Інтеграційні процеси в сучасній початковій освіті.

У статті розглянуто питання інтеграційних процесів у сучасній початковій школі: проблеми та перспективи. Проаналізовано головні аспекти, причини i тенденції розвитку інтеграційних процесів, що безпосередньо стосуються змісту початкової освіти.

Ключові слова: інтеграція, інтеграційні процеси, початкова школа, навчання.

Якименко С. И. Интеграционные процессы в современном начальном образовании.

В статье автор рассматривает вопрос интеграционных процессов в современной начальной школе: проблемы и перспективы. Анализирует главные аспекты, причины и тенденции развития интеграционных процессов, которые непосредственно касаются содержания начального образования.

Ключевые слова: интеграция, интеграционные процессы, начальная школа, учеба.

Yakymenko S. I. Integration processes in modern primary education.

In this article the author considers questions of integration processes in the modern primary school : problems and prospects. The author analyzes the main aspects, reasons and tendencies of development of integration processes that relate directly to the contents of primary education.

Key words: Integration, integration processes, primary school, education.

Інтеграційні процеси в освіті - явище досить складне, комплексне і різнобічне за різновидами свого вияву, яке вимагає аналізу психологічної й педагогічної позицій.

Основна мета навчання на інтегративній основі - надати цілісне уявлення про навколишній світ - пов'язана 3 підвищенням розумової активності учнів, а отже, необхідне визначення психофізіологічних основ інтеграції знань, чітке уявлення про 